a diacono dicente: Catechumini procedant ... Postea ammonentur a diacono ita: Catechumini recedant. Si quis catechuminus est recedat. Omnes catechumin exeant foras. Et egrediuntur. Exactly the same in the 'Gellone' Sacramentary, the Poitiers Pontifical, \&c., quoted by Martene (Ant. Eccl. Rtt. i, c. I, art. xii, cols. I00-1 I 2); once accedant is found instead of procedant for the entry, and once only (col. 118) procedant for the dismissal. The Rheims Sacramentary (ed. Chevalier pp. 346-35 I) bears the same witness ${ }^{1}$.

The question then cannot as yet be regarded as settled; should it eventually be proved that our formula here as elsewhere is the original missa catechumenorum, we shall not regret the present discussion in our joy at the discovery of a long-lost office. In any case it is a point gained to have been able to couple together the southern with the northern Italian rites and to have added another link to the chain of evidence which is gradually bringing to light the original Roman rite.

H. M. Bannister.

\title{
CURRENT MUHAMMADAN TEACHING AS TO THE GOSPELS.
}

THE following is a translation, slightly abbreviated, of the Life of Hazrat'Isa (Jesus), written by a Maulawi of literary repute in Delhi. The teaching contained in it would be that given to orthodox Muhammadans to-day in the North of India.

'Muhammadans acknowledge that Hazrat 'Isa was a great Prophet, and believe that Hazrat Mariam was free from sin and chosen of God, and that the birth of Hazrat 'Isa was not without miracle. For this matter is narrated at length in the Quran.

'The people of Islam do not only believe those miracles which are

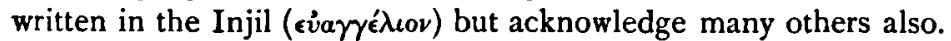

'Hazrat 'Isa was born at Bait-ul-Lahm, which is a village near Baitul-muqaddas (Jerusalem). Hazrat Mariam was at first anxious as to what answer she should give, if people should ask her about her child. It came to pass that the people of her tribe, looking for her, came to her and asked her " $\mathrm{O}$ sister of Harun (Aaron), what have you done, and from whence have you brought this child?"

\footnotetext{
${ }^{1}$ It is again necessary to call attention to Chevalier's editing-on p. $35 \mathrm{I}$ secedat is probably an error for recedat, and the ommes catecumini exeant foras which he prints as a rubric is undoubtedly the third clause of the dismissal formula.
} him."

'Hazrat Mariam pointed to Hazrat 'Isa, and said, "Enquire from 
"With the power of God Hazrat 'Isa began at once to say, "I am the Servant of God, and He has given me a Book and Prophecy."

'Seeing this miracle they left Hazrat Mariam.

'After this Hazrat Mariam took Hazrat 'Isa with her and went to Egypt and remained there for twelve years and then coming to Syria stayed at Nāsara, remaining there till about the thirtieth year of his age. Then God Almighty sent him a Revelation and ordered him to guide the people and gave him the Book of Injil.

'It is written in Muhammadan books that when Hazrat 'Isa reached the thirtieth year he went to Nahr-i-Jardan (i.e. River Jordan) which is also called Shari'a and there guided the people towards God. In this stream, according to the custom, Yahya the prophet (1. e. John the Baptist) baptized Hazrat 'Isa and received him among his disciples. At this time the death of Hazrat Yahya was near.

'When Hazrat 'Isa was engaged in preaching he showed many miracles to the People in proof of his Prophecy, such as raising the dead to life, making birds out of clay and breathing life into them, restoring blind men and lepers, walking on the water, as well as many other miracles whıch God Almighty had given him. His chief associates and helpers were twelve men who are called Hawāi (Companions). These often abode with him and were at all times obedient to him. One day, on a journey, they asked him for a Heavenly Tray. Hazrat 'Isa prayed two portions of the public prayer, and a heavenly tray containing many kinds of food descended from the skies, and all of them ate from the tray and tasted the most delicious food. After this it continued to descend from time to time and the people ate out of it. But, later on, the wayward ones began to be doubtful and ungrateful, and therefore, instead of a tray of delights, tortures began to descend.

'It is written in the books of Islam that at this time there was a Jewish king, a great tyrant, obstinate and proud. Hazrat 'Isa instructed him in religion, but he did not obey and planned to kill Hazrat 'Isa. Therefore Hazrat 'Isa sent for his Companions and made his testament thus, "After me a Prophet will be born in the tribe Quraish, in Arabia ; do you instruct your children from generation to generation that they who are alive at that time must embrace that Prophet's religion."

'One of the Companions whose name was Jehuda Iskarioti became wayward and went to the Jewish Ruler and asked, "What reward will be given me if I betray Hazrat 'Isa ?" The Ruler offered thirty drachmas, and he took the money and pointed out the place where Hazrat 'Isa was.

'The Jews, who were his deadly enemies, determined now to crucify Hazrat 'Isa, but by the order of Almighty God Hazrat Gabriel came and took Hazrat 'Isa up into heaven and changed the form of Jehuda 
the traitor into the form of Hazrat 'Isa. The Jews then dragged Jehuda to the Ruler and put him to shame on the road, some buffeting hrm, some casting thorns upon his head, some saying, "You, who restored the dead to life, why do you not deliver yourself?"

'Although Jehuda took many oaths, yet they did not trust him, but dragged him before their Rulers and crucified him. Some of the relations of Hazrat 'Isa asked for the dead body from Pilatus, who was ruler of the Jews under the king of Rutm, and they buried the body in a tomb.

'Isma'il Abu'l Fida in his Arabic History (whose name is 'Brief Account of the news of Mankind') relates that after this event, Hazrat 'Isa descended from Heaven and appeared to his mother. She, thinking that the tomb of Jehuda was that of her son, was weeping at the tomb. Hazrat 'Isa said, "God has called me unto himself: go and call my Companions." When they came he said to them, "Go into all the world and guide the People. Go to different places and preach the Gospel."

' $\mathrm{He}$ then ascended into Heaven, and the Companions, according to his command, dispersed and preached. Then Hazrat Matti, Luqā, Marqus, and Juhanna each compiled an Injil.

'Muhammadans think that Hazrat 'Isa is alive and that he will come again into this world. For it is written in the "Books of the signs of the Day of Resurrection" that at first there will be a great spread of Christians all over the earth. Then a Muhammadan named Imām Mahdi will be born and will give great glory to Islam.

'After that an Infidel, whose name is Dajjal, will appear, and by his deceits will entice the people to become Infidels and will teach them to worship himself.

'Then Hazrat 'Isa descending from the skies will accept Islam. He will join with Hazrat Imām Mahdi and they will try hard to destroy Dajjal and his friends, so that all the People will embrace Islam and there will be very great Progress and Splendour.'

Such is the account of the Gospel Story as accepted by orthodox, educated Muhammadans to-day in Northern India. I have often heard them bring forward such points as the Making of Birds out of Clay or the Feeding from the Heavenly Tray. I have listened also to a leading Maulawi in Delhi arguing controversially with Maulawi Ahmad Masih, before an audience of some 400 Muhammadans, that it was Judas Iscariot who was crucified, and not our Blessed Lord. The only other point, which I have heard frequently mentioned, is the well-known one that our text in St John xv 26 ö and that the original Greek was the translation of the name Muhammad

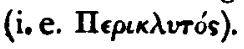


We are looking forward eagerly to $\mathrm{Mr}$ Lonsdale Ragg's edition of the Italian version of the Gospel of Barnabas which should clear up many points.

C. F. ANDREws.

\section{AMBROSIASTER AND DAMASUS.}

I. The Deacon with the Pagan Name. 2. Rector. 3. Paganus.

Circumstances having hindered for the moment the completion of a review of Mr Souter's Study of Ambrosiaster which I had hoped to contribute to the present number of the JoURNAL, I take the opportunity of publishing separately some fragmentary notes tending to shew how the writings of Ambrosiaster-the Commentaries on St Paul and the Quaestiones Veteris et Novi Testamenti-and of his contemporary pope Damasus mutually explain and illustrate one another.

\section{The Deacon with the Pagan name.}

Among the 3,000 corrections which $\mathrm{Mr}$ Souter claims to have made from the MSS in the text of the Quaestiones, few are more curious than the new form which is now taken by the reference to the name of a Roman deacon in the celebrated Quaestio cI, De iactantia Romanorum Levitarum. Where all the editions have printed 'quidam igitur qui nomen habet Falcidii', the true reading, as recovered by him from the older MSS, is 'quidam igitur qui nomen habet falsi dei'. But who was this deacon who bore the name of a pagan god? Mr Souter could only suggest (op. cit. p. 1 70) a certain Concordius mentioned in the Liber Pontificalis. Yet that name would, I think, have suggested associations with the Christian virtue of concord rather than with the pagan divinity Concordia : and a passage in the epigrams of Damasus supplies a more satisfactory answer to the question. On the new font into which that active and energetic pope drew off the waters of the Vatican hill were inscribed some verses recording his proceedings and naming his clerk of the works, 'the faithful levite Mercury'; see no. iv in Ihm's edition of the Damasi Epigrammata, Anthologiae Latinae supplementumi, in the Teubner series, A.D. I 895 -

cingebant latices montem teneroque meatu corpora multorum cineres atque ossa rigabant. non tulit hoc Damasus, communi lege sepultos post requiem tristes iterum persoluere poenas. protinus adgressus magnum superare laborem aggers inmensi deiectt culmina montıs. 